Working Paper No. 04/04

\title{
Market Potential in British Regions, 1871-1931
}

\author{
Nicholas F. R. Crafts
}

(C) Nicholas F. R. Crafts

Department of Economic History

London School of Economics 
This project is funded by the ESRC under grant 2394/R000239536, "Large-Scale Technological Change", and is directed by Professor N. F. R. Crafts.

For further details about this project and additional copies of this, and other papers in the series, go to:

http://www.Ise.ac.uk/collection/economichistory/

Department of Economic History

London School of Economics

Houghton Street

London, WC2A 2AE

Tel: $\quad$ +44 (0) 2079557860

Fax: $\quad$ +44 (0) 2079557730 


\begin{abstract}
This paper constructs measures of market potential for British regions based on the spatial distribution of GDP and its accessibility. The results show that the North, Scotland and Wales were much less 'peripheral' before World War I than in 1985. The main reason for the deterioration in their position was changing transport costs. The marginalization of coastal shipping and the rise of road haulage had markedly accentuated the 'peripherality' of outer Britain by 1931. The sensitivity of market potential to changes in relative transport costs has gone unnoticed but it underlines the danger of conflating 'peripherality' with competitiveness.
\end{abstract}

KEYWORDS: Market Potential; Peripherality; Regional Differences

\title{
Introduction
}

It is well-known that regional disparities in income in the late twentieth century were different from the situation prior to World War I, although precise measurement has been elusive. The general picture set out by writers like Lee, 1971 is that the South East was the fastest growing region during the twentieth century while outer Britain was in relative economic decline. In turn, this experience is related to the South East's increasing advantage in market access which is often thought to have been advantageous at a time when agglomeration economies,

\footnotetext{
* Funding from the Economic and Social Research Council under grant R000239536 is gratefully acknowledged. I have gained from helpful discussions with Dudley Baines, Steve Broadberry, Eddie Hunt, Tim Leunig, Brian Mitchell, Abay Mulatu, Peter Scott and Jim Taylor. Iain Begg and Frank Geary generously made data available to me. The usual disclaimer applies.
} 
economies of scale and declining transport costs increasingly informed location decisions.

Yet full description of the earlier picture of market access has not been provided. This is unfortunate because research in the tradition of new economic geography suggests that it may indeed an important ingredient in industrial location decisions (Midelfart-Knarvik et al., 2000). However, recent research on regional income levels and on transport costs in the late nineteenth and early twentieth centuries now makes possible an estimate of regional economic potential in Britain, defined in the sense of Keeble et al., 1982. This permits comparisons with estimates for 1985.

Economic potential depends on levels of GDP in the home region and of GDP in other areas adjusted for their proximity. Proximity depends on distance over land and sea where sea miles are converted into miles over land by estimating an equivalent transport cost. Relatively low regional economic potential is often equated with 'peripherality'. Changes over time in economic potential can be the result of either differential economic growth or of distance as the relative cost of sea and land transport varies over time. At the start of the twentieth century goods were transported by rail and steamship but a hundred years later these modes had been superseded by ferries and trucks.

Accordingly, this paper provides estimates of economic potential for British regions in the census years from 1871 to 1931 and uses them to address the following questions:

1) How did the pattern of 'peripherality' in earlier years compare with that of 1985 ?

2) How sensitive are estimates of economic potential to changes in relative transport costs? 
The results show substantial movement in relative regional economic potential over time. It seems highly probable that these were much more dramatic than any changes in underlying regional economic competitiveness. This underlines the danger of relating 'peripherality' purely to distance which has rightly been stressed by NIEC (1994).

\section{Regional Economic Potential}

Regional economic potential measures the centrality of each region. The concept can be calculated using the following formula

$$
P_{i}=\Sigma\left(M_{j} / D_{i j}\right)
$$

where $\mathrm{P}_{\mathrm{i}}$ is the potential of region $\mathrm{i}, \mathrm{M}_{\mathrm{j}}$ is a measure of economic activity (typically GDP) in region $\mathrm{j}$ and $\mathrm{D}_{\mathrm{ij}}$ is a measure of the distance, or cost of transport, between $\mathrm{i}$ and $\mathrm{j}$. A traditional version of this formula is

$$
P=\Sigma G D P_{j} d_{i j}
$$

where $d_{i j}$ is the bilateral distance between locations $i$ and $j$ and $\gamma$ is a distance weighting parameter traditionally set at -1 . This needs to be augmented by a measure of 'own distance' for self potential. Keeble et al., 1982 suggest that this can be approximated by the formula

$$
\mathrm{d}_{\mathrm{ii}}=0.333 \sqrt{ }(\text { area of region } / \pi)
$$

which gives a distance value one third of the radius of a circle the same area as region $\mathrm{i}$. These assumptions are also adopted here. If transport 
involves more than one mode, distance has to be based on an equivalence between modes based on relative cost.

The notion of regional economic potential can also be thought of as representing market access or market potential. This last term has been adopted by the new economic geography which has led to renewed interest in the concept. In this tradition, the centrality of a location is expected to be a powerful influence on firms' decisions on where to locate. For example, industries with higher economies of scale may tend to concentrate in more central locations as may firms which are highly dependent on inputs of intermediate goods or firms which desire to be near their customers. These arguments tend to matter when transport costs are neither very high nor very low but are 'intermediate' (MidelfartKnarvik et al., 2000).

\section{Ingredients Of Market Potential}

To estimate market potential requires data on GDP of home regions and foreign countries and also measures of distances based on relative transport costs between these locations. Each of these necessitates some choices about procedure on the part of the investigator.

Until recently, there have been no data on regional GDP before 1971. Geary and Stark, 2002 set out a proxy method for using information on employment and wages which they used to obtain estimates for Ireland, Scotland and Wales for 1871-1911. These results are extended to the remaining British regions and refined by using income tax assessments to allocate non-wage income in Crafts, 2004. For 1921 and 1931, the Geary-Stark method can again be employed but for these years it is not possible to make any adjustment to incorporate evidence from the geography of income tax assessments since these 
were no longer published. The resulting estimates of regional GDP are shown in Table $1{ }^{1}$

GDP of European countries and big trading partners, India and the United States, will also be considered as relevant to market potential. This could be measured in $£$ using either current or purchasing power parity exchange rates. The former seem preferable in that this is what mattered to agents at the time but it should be noted that in the interwar period exchange rates were highly volatile and the relative size of these economies is very sensitive to the year that is selected. Estimates of relative income levels converted at prevailing exchange rates have been extracted primarily from Prados De La Escocura, 2000. The results are shown in Table 2. Together with the estimates for home regions reported in Table 1, these will be used to calculate economic potential.

Before the development of motorized road freight, coastal shipping was a key component of British internal transport. Armstrong, 1987 estimated the proportion of ton-miles carried in 1910 by coastal shipping as $59 \%$, compared with $39 \%$ by railways and $2 \%$ by canal. The coaster dominated in long hauls except where speed was of the essence. Accordingly for 1871 to 1921, the transport mode for distances between British regions was defined as the cheaper of rail or rail and ship based on shipping rates estimated by Kaukiainen, 2003. He examined both terminal charges and costs per ton-mile based on data in Fairplay. His regressions dealt with grain and coal (which are taken to be representative cargoes in an era prior to specialized shipping) and he provides estimates for selected years. Table 3 reports averages of his grain and coal estimates in current prices.

1 Details of this methodology are set out in the appendix which also demonstrates that all the main conclusions of the paper are robust to dropping the income tax refinement and relying on the basic Geary-Stark method throughout. 
For rail transport distances between a designated 'node' in each region have been obtained from Bradshaw's Railway Guide and for journeys between port and 'node' in European countries from Foxwell and Farrer, 1889. For India and the United States the ports of Bombay and New York are taken to be the relevant nodes. The length of sea journeys has been estimated using Dataloy Systems at www:dataloy.com/newwebsite/index.php. The costs of these sea journeys were converted into rail-equivalent miles using the average charge per ton-mile on British railways for each year reported in Cain, 1980, Table 5 and Walker, 1942, p. $130{ }^{2}$

Even in 1921, road transport accounted for only $6.3 \%$ of combined road and rail ton-miles. After that costs of road freight fell rapidly and it became the preferred mode for most goods at distances up to about 100 or 120 miles by the early 1930s at which point coastal shipping had become marginalized and was used mainly for conveying coal (Scott, 2002). Thus, for 1931, internal hauls up to 130 miles are assumed to be by road, over 130 miles by rail, and shipping is only taken into account for international transportation. Including collection and delivery, road haulage had a lower fixed cost component but a higher marginal cost than rail; accordingly, after the break-even point of 130 additional miles are regarded as 2/3 mile to reflect the tapering of rail charges (Walker, 1942, Figure 4). For 1931 the conversion of sea miles into road miles is accomplished by taking the fixed port handling and foreign road transport fixed costs to equate to an extra 143 home road miles and sea miles to have a marginal cost of 1/50 road mile based on Kaukiainen, 2003 and Walker, 1942.

One further aspect is relevant in taking account of foreign countries in measuring market potential, namely, the additional 'distance equivalent'

\footnotetext{
${ }^{2}$ Rail freight receipts were dominated by similar commodities.
} 
of tariff barriers to trade. ${ }^{3}$ The paper by Estevadeordal et al., 2002 facilitates a way to convert tariffs into an equivalent shipping cost. These authors estimate a gravity model for trade which has a distance elasticity $=-0.8$ and a tariff elasticity $=-1.0$ (where the tariff is measured as $(1+$ t)). Based on 1913, Table 3 shows that raising distance by 100 per cent from 500 to 1000 miles cost an extra $(5 \times 0.168)=0.84$ shillings per ton which is equivalent to raising the tariff by 80 per cent from 1 to 1.8 . So each 1 percentage point of tariff is equivalent to an additional $0.84 / 80=$ 0.0105 shillings to be added to the intercept of the equations in Table 3 . Similar adjustments for other years have been implemented using the summary estimates of average tariffs facing British manufactured exports given in (Bairoch, 1993, p. 24, 26).

Using these ingredients, Table 4 reports estimates of market potential from 1871-1931. An interesting feature is that the rather low distance to India and the USA in terms of rail equivalent miles implies that they loom quite large in all regions' market potential (a bit less for landlocked regions). This makes sense in the context of trade flows. At this point Continental Europe was less important proportionately as a destination for British exports than it became in the late twentieth century while India was much more prominent. ${ }^{4}$

\section{Comparisons Of Market Potential Over Time}

Changes in market potential over time can result from either or both of a shift in the spatial distribution of GDP or in relative transport costs. The latter might occur as the comparative attractiveness of

\footnotetext{
${ }^{3}$ Non-tariff barriers to trade proliferated in the 1930s but can be regarded as unimportant through 1931; see Gordon, 1941.

${ }^{4}$ In 1911 India accounted for exports of $£ 53.9$ million compared with $£ 57.4$ million to Germany; in 1980 exports to India were $£ 529.2$ million and to Germany $£ 5109$ million, MITCHELL, 1988, pp. 507-13.
} 
different transport modes is transformed by technological progress. Historically, the crucial development was the move to motor transport which began after World War I and was more or less complete by the 1960s. In contrast, prior to World War I coastal shipping would be preferred to rail between many British cities (for example, LondonGlasgow, London-Newcastle); this implies that in rail-equivalent miles both Glasgow and Newcastle were closer to London than Leeds.

Table 5 reports relative 'distances' in 1911, 1931 and 1985 and shows a striking discrepancy in the proximity of North, Wales and Scotland to London across these years. The demise of coastal shipping and the advent of road haulage meant a dramatic change in the position of the North, Scotland and Wales between 1911 and 1931 as these parts of outer Britain were no longer 'closer' to London than the landlocked midlands. As road took over from rail more or less entirely in recent times this loss of proximity to London and the South East was reinforced.

It is possible to compare the regional differentials implied by the estimates of market potential in Table 4 with those for the recent past found by NIEC (1994). In order to make the results broadly comparable, London and South East have been aggregated and market potential has been assessed on the basis of UK regions and European countries (i.e., omitting India and USA from the calculation). Three points stand out from Table 6. First, relative to pre-World War I days only the land-locked midlands regions had a better relative position in 1985. Second, by contrast, outer Britain was far more disadvantaged with North, Wales and Scotland much more 'peripheral' in 1985; a good deal of this ground had already been lost by 1931 . Third, no region in 1985 had nearly as strong a position relative to South East as did North West in 1871-1931.

In Table 7 the reasons for these differences between 1911 and 1985 and between 1931 and 1985 are explored by examining the implications of using the other year's distance data to calculate market 
potential. Four points should be noted. First, if 1985 distances are used, then in both 1911 and 1931 relative market potential in North, Scotland and Wales looks much worse and very similar to 1985. Second, conversely, if 1911(1931) distances are used to calculate 1985 market potential, then relative to London \& South East outer Britain looks much like its 1911(1931) level. Third, it makes little difference to the relative position of the northern industrial regions (North West, Yorkshire \& Humberside) which year's distances are used. Fourth, for the midlands regions, the use of 1985 rather than 1911 or 1931 distances strengthens their relative position appreciably, and virtually all their improved relativity in 1985 compared with 1911 can be attributed to the replacement of historical distance equivalents with their modern counterparts.

Taken together, these results suggest that developments in relative transport costs have been much more important than shifts in the spatial distribution of GDP in accounting for changes during the twentieth century in the relative market potential of British regions. In particular, as the world moved from rail and ship to road and ferry the 'peripherality' of the North, Wales and Scotland was seriously accentuated.

\section{Discussion}

The sensitivity of estimates of market potential to changes in transport costs has received relatively little attention in the literature using the concept which has been more concerned with the impact of reductions in tariff barriers associated with the enlargement of the European Union (Clark et al., 1969; Keeble et al., 1982). The results of this paper suggest that the methods chosen to convert distances into their equivalents under a different transport mode may deserve further investigation since they can have a substantial impact on market potential estimates. Alternatively, given the difficulty of obtaining data on transport 
costs as trade becomes ever more complex, where data on trade flows permit, it may be preferable to estimate the distance weighting parameter, $\gamma$, using a gravity model of trade as in Leamer, 1997.

Much previous research has tended to assume that the differences in accessibility reflected by estimates of market potential may have significant implications for regional economic performance through their impact on firms' location decisions. This has been challenged by NIEC (1994) in its review of the implications of 'peripherality' for the Northern Irish economy. The point that is made there is that it is not distance per se that matters for regional competitiveness but to what extent remoteness imposes a penalty on the region and that 'peripherality' should be reconceptualized in these terms.

This issue can be addressed by econometric models that relate industrial location decisions to market potential along with other regional characteristics such as factor endowments in the context of differences in industrial factor intensities, susceptibility to linkage effects and scale economies. Midelfart-Knarvik et al., 2000 find support for the role of market potential interacted with linkage effects for location decisions in the European Union in the 1990s but not earlier but do find evidence that industries subject to scale economies were attracted to central regions in the 1970s and 1980s. Crafts and Mulatu, 2004 estimate a similar model for British regions from 1871 to 1931 and conclude that the dominant influence on location decisions at that time was factor endowments. Taken together, these results suggest that the loss of relative market potential experienced by outer Britain during the twentieth century probably had relatively little adverse effect on regional competitiveness before the recent past. Thus, although ostensibly outer Britain was considerably more 'peripheral' in 1931 than it had been twenty years earlier, in practice the handicap that this imposed was not severe. As shrewd observers noted at the time, outer Britain's problems in the 
interwar period stemmed from the difficulties of the Victorian staple industries rather than lack of accessibility to markets (Great Britain, 1940).

\section{Conclusions}

This paper has used the concept of regional economic potential or market potential, as defined by Keeble et al, 1982, to examine the changing centrality of British regions over time. Two main conclusions have emerged with respect to the questions posed in the introduction.

1) Compared with the early twentieth century in 1985 the North, Scotland and Wales were much more 'peripheral'.

2) The driving force of changes in the 'peripherality' of these regions was the rise of road transport and the demise of coastal shipping whereas changes in the spatial distribution of GDP played little part.

At the same time, it seems likely that for most of the twentieth century this had relatively little effect on regional competitiveness since market potential appears to have little effect on the location of industry.

Previous research in this area has been focused on the recent past where perhaps relative transport costs have been more stable than over the long run. At the same time, an important message from this paper is that calculations of market potential can be quite sensitive to changes in transport costs and this may be a valuable point to bear in mind as we confront the so-called 'death of distance' in the new era of globalization. 


\section{APPENDIX}

The Geary-Stark method of estimating regional GDP uses data on employment structure (agriculture, industry, services) and sectoral wages together with estimates of UK output for each sector. It assumes that regional sectoral productivity relative to the UK average is reflected in sectoral regional wages relative to the UK average.

UK GDP is defined as

$$
\mathrm{Y}_{\mathrm{UK}}=\Sigma \mathrm{Y}_{\mathrm{i}}
$$

where $Y_{i}$ is GDP of region i which is in turn defined as

$$
Y_{i}=\Sigma y_{i j} L_{i j}
$$

where $y_{i j}$ is average value-added per worker in country $i$ in sector $j$ and $L_{i j}$ is the corresponding number of workers.

Then assume that

$$
Y_{i}=\Sigma\left[y_{j} \beta_{j}\left(w_{i j} / w_{j}\right)\right] L_{i j}
$$

where $y_{j}$ is UK output per worker in sector $\mathrm{j}, \mathrm{w}_{\mathrm{ij}}$ is the wage paid in region $\mathrm{i}$ in sector $j$ and $w_{j}$ is the national average wage in sector $j . \beta$ is a scalar which preserves the relative regional differences but scales the absolute levels so that regional totals for each sector sum to the known UK total. More details can be found in Geary and Stark, 2002 where it is reported that this method does well in replicating regional GDP in 1971 the first year for which full regional accounts are available. 
The resulting pattern of regional GDP in the years 1871 to 1911 is, however, rather different from that of the income tax assessments. In that period income tax was levied essentially on non-wage incomes. A refinement of the Geary-Stark method, which has been adopted in obtaining the estimates given in Table 1 of this paper, is to use their procedure to allocate wage income across regions and the tax data to allocate non-wage income. Details of this procedure are given in Crafts, 2004.

Appendix Table 1 reports the estimates for relative market potential which would be obtained if the unrefined Geary-Stark method were used throughout. Comparison of these results with those reported in Table 6 shows that the discrepancies between them are minor and they make no material difference to any of the conclusions reached in this paper. 
Table 1. Regional GDP, 1861-1931, £ mn current

$\begin{array}{lllllll}1871 & 1881 & 1891 & 1901 & 1911 & 1921 & 1931\end{array}$

UK

London

Rest South East

East Anglia

South West

West Midlands

East Midlands

North West

Yorks \& Humb

North

Wales

Scotland $\begin{array}{lllllll}1208 & 1307 & 1495 & 2049 & 2330 & 5134 & 4359\end{array}$

$\begin{array}{lllllll}203.7 & 231.8 & 298.4 & 423.9 & 500.0 & 949.8 & 775.9\end{array}$

$\begin{array}{lllllll}133.4 & 139.3 & 157.2 & 231.8 & 279.3 & 590.4 & 688.7\end{array}$

$\begin{array}{lllllll}40.7 & 38.0 & 36.5 & 43.0 & 47.1 & 118.1 & 95.9\end{array}$

$\begin{array}{lllllll}85.7 & 87.2 & 86.5 & 108.8 & 125.2 & 267.0 & 248.5\end{array}$

$\begin{array}{lllllll}77.2 & 84.0 & 89.0 & 125.2 & 137.3 & 410.7 & 344.4\end{array}$

$\begin{array}{lllllll}71.7 & 76.4 & 84.5 & 112.1 & 130.7 & 333.7 & 265.9\end{array}$

$\begin{array}{lllllll}146.6 & 166.5 & 194.6 & 262.1 & 297.4 & 775.2 & 605.9\end{array}$

$\begin{array}{lllllll}83.0 & 94.5 & 109.9 & 151.6 & 170.4 & 462.1 & 374.9\end{array}$

$\begin{array}{lllllll}61.4 & 66.2 & 78.6 & 106.4 & 119.2 & 318.3 & 231.0\end{array}$

$\begin{array}{lllllll}51.4 & 56.6 & 70.8 & 93.7 & 116.6 & 261.8 & 200.5\end{array}$

$\begin{array}{lllllll}123.9 & 141.0 & 163.4 & 240.8 & 260.0 & 646.9 & 527.4\end{array}$

Source: Crafts, 2004. For 1871 to 1911 Ireland is included in the UK total. For 1921 and 1931, Geary-Stark method is implemented disregarding Ireland and Northern Irish GDP (about 2 per cent of the UK total is distributed pro rata across the mainland regions) and there is no correction for income tax assessments. The employment data required to implement this method are from Lee, 1979 and the wage rate estimates are from Ministry Of Labour, 1921, 1929, 1931 and, for Scottish agriculture, from Anthony, 1993. 
Table 2. Foreign GDP (£mn current).

$\begin{array}{lrrrrrrr} & \mathbf{1 8 7 1} & \mathbf{1 8 8 1} & \mathbf{1 8 9 1} & \mathbf{1 9 0 1} & \mathbf{1 9 1 1} & \mathbf{1 9 2 1} & \mathbf{1 9 3 1} \\ \begin{array}{lrrrrr}\text { Austria- } \\ \text { Hungary }\end{array} & \mathbf{4 0 3 . 5} & 396.0 & 524.7 & 674.1 & 801.5 & 1373.0 & 1076.8 \\ \text { Belgium } & & & & & & & \\ \text { Denmark } & 186.0 & 202.6 & 224.2 & 266.4 & 314.6 & 609.2 & 451.1 \\ \text { France } & 38.7 & 43.1 & 55.3 & 77.9 & 116.5 & 322.0 & 294.1 \\ \text { Germany } & 931.4 & 945.0 & 1160.1 & 1370.8 & 1822.1 & 3528.6 & 2568.7 \\ \text { India } & 695.8 & 828.6 & 1243.8 & 1774.4 & 2476.8 & 5145.8 & 4103.4 \\ \text { Ireland } & 583.8 & 579.2 & 477.2 & 570.6 & 808.0 & 2097.2 & 1977.2 \\ \text { Italy } & 129.3 & 126.8 & 125.6 & 149.6 & 146.8 & 300.2 & 143.1 \\ \text { Netherlands } & 437.3 & 471.8 & 517.3 & 592.2 & 848.1 & 1985.9 & 1646.9 \\ \text { Norway } & 78.5 & 91.5 & 112.1 & 137.3 & 186.4 & 511.5 & 499.5 \\ \text { Portugal } & 32.6 & 36.6 & 43.4 & 65.6 & 93.2 & 245.0 & 219.7 \\ \text { Spain } & 45.9 & 49.7 & 65.8 & 63.5 & 86.2 & 179.6 & 145.7 \\ \text { Sweden } & 271.8 & 349.0 & 352.8 & 346.3 & 477.6 & 1142.6 & 1017.5 \\ \text { USA } & 101.5 & 70.6 & 85.2 & 137.3 & 200.4 & 519.8 & 465.9 \\ & 1471.3 & 2155.2 & 2821.1 & 4067.3 & 6631.2 & 19000.4 & 19563.4\end{array}$

Source: derived from Prados De La Escocura, 2000 except India from Heston, 1983 and from Sivasubramonian, 1997, and Ireland from Geary and Stark, 2002 and from O'Grada, 1994. After the end of the AustrianHungarian empire, Austria-Hungary is the sum of Austria, Czechoslovakia and Hungary. Estimates for 1921 are the average of 1913 and 1929 except for India and Ireland. 
Table 3. Shipping Rates per ton (current price in shillings).

$\begin{array}{ll}\begin{array}{l}\text { Terminal Component } \\ \text { (Constant) }\end{array} & \begin{array}{l}\text { Per } 100 \text { Miles } \\ \text { (Coefficient) }\end{array}\end{array}$

$\begin{array}{lrl}1872-4 & 13.264 & 0.3815 \\ 1879-80 & 11.040 & 0.2500 \\ 1888-9 & 8.708 & 0.1680 \\ 1898-9 & 6.572 & 0.1520 \\ 1911-3 & 5.810 & 0.1680 \\ 1921-2 & 11.677 & 0.2300 \\ 1926-7 & 7.908 & 0.2160\end{array}$

Source: Kaukiainen, 2003: average of estimates for grain and coal. 
Table 4. Market Potential (£mn)

$\begin{array}{lrrrrrrr} & \mathbf{1 8 7 1} & \mathbf{1 8 8 1} & \mathbf{1 8 9 1} & \mathbf{1 9 0 1} & \mathbf{1 9 1 1} & \mathbf{1 9 2 1} & \mathbf{1 9 3 1} \\ & & & & & & & \\ \text { London } & 81.3 & 97.0 & 128.4 & 191.8 & 239.9 & 420.5 & 374.5 \\ \text { Rest South East } & 35.7 & 43.2 & 56.6 & 84.2 & 119.6 & 203.6 & 199.9 \\ \text { East Anglia } & 31.0 & 37.9 & 52.3 & 80.5 & 108.1 & 180.6 & 173.9 \\ \text { South West } & 35.2 & 44.3 & 60.1 & 93.9 & 124.0 & 203.0 & 187.2 \\ \text { West Midlands } & 30.6 & 36.9 & 46.5 & 67.5 & 88.4 & 181.0 & 164.5 \\ \text { East Midlands } & 28.8 & 34.5 & 43.7 & 62.9 & 82.8 & 168.9 & 157.8 \\ \text { North West } & 40.6 & 50.1 & 65.7 & 97.1 & 125.4 & 242.1 & 222.1 \\ \text { Yorks \& Humbs } & 32.8 & 40.4 & 52.4 & 78.7 & 102.4 & 198.1 & 185.4 \\ \text { North } & 31.4 & 40.7 & 56.9 & 91.1 & 119.6 & 192.2 & 173.3 \\ \text { Wales } & 33.7 & 43.7 & 59.8 & 94.0 & 125.9 & 200.3 & 183.8 \\ \text { Scotland } & 29.9 & 39.6 & 55.5 & 89.4 & 117.5 & 185.3 & 160.4 \\ & & & & & & & \\ \text { London/SE merged } & 44.3 & 54.6 & 73.4 & 113.9 & 148.1 & 247.7 & 238.5\end{array}$

Source: see text. 
Table 5. Relative 'Distances' from London in 1911, 1931 and 1985

East Anglia

South West

West Midlands

East Midlands

North West

Yorkshire \& Humberside

North

Wales

Scotland
1911

1931

1985

\author{
60.7
}

105.4

100

109.8

102.7

112.5

67.9

72.3

75.9
60.7

105.4

100

109.8

150.9

149.1

198.2

125.0

277.7
101.1

105.6

100

111.9

172.9

172.9

256.5

145.8

363.8

Source: see text. In each year the benchmark, London to Birmingham, is set at 100 and other distances are expressed relative to this. In 1985 road is assumed to be the cheapest option and all distances are measured in terms of road kilometres as in NIEC, 1994. In 1911 it is assumed that coastal shipping is used for the whole or part of a journey where it is cheaper and distances are converted into rail-equivalent kilometres before expressing them relative to the rail distance from London to Birmingham, see text. In 1931, road is taken to be cheaper up to 130 miles above which rail would be preferred and the marginal cost of additional miles is charged at $2 / 3$ of a road mile and coastal shipping is disregarded based on the data in Walker, 1942. For East Anglia this paper uses Ipswich as the node whereas NIEC uses Norwich. 
Table 6. Market Potential Relative to London and South East (\%)

$\begin{array}{llllllll}1871 & 1881 & 1891 & 1901 & 1911 & 1921 & 1931 & 1985\end{array}$

$\begin{array}{lrrrrrrrr}\text { East Anglia } & 65.1 & 62.4 & 64.4 & 63.3 & 64.8 & 62.7 & 59.1 & 53.7 \\ \text { South West } & 74.4 & 74.2 & 74.1 & 73.2 & 73.5 & 71.1 & 66.4 & 59.4 \\ \text { West Midlands } & 67.6 & 66.3 & 62.3 & 58.3 & 57.6 & 71.5 & 68.2 & 70.2 \\ \text { East Midlands } & 63.2 & 61.7 & 58.6 & 54.1 & 54.0 & 66.0 & 62.9 & 65.6 \\ \text { North West } & 91.8 & 92.6 & 90.9 & 86.2 & 84.6 & 100.8 & 94.5 & 78.7 \\ \text { Yorks \& Humb } & 72.2 & 72.0 & 69.8 & 68.0 & 67.0 & 78.5 & 74.8 & 65.6 \\ \text { North } & 64.0 & 66.5 & 69.2 & 71.1 & 70.6 & 66.1 & 57.6 & 45.7 \\ \text { Wales } & 70.3 & 72.7 & 73.5 & 73.2 & 75.1 & 69.5 & 63.5 & 50.9 \\ \text { Scotland } & 59.9 & 63.2 & 65.3 & 67.6 & 66.6 & 60.3 & 51.5 & 34.9\end{array}$

Source: derived from data underlying Table 4 and, for 1985, from NIEC, 1994.

London and South East are aggregated and India and USA are omitted from the calculation. 
Table 7. Market Potential Relative to London \& South East, 1911, 1931 and 1985: the Impact of Changes in Relative Transport Costs

$\begin{array}{lccccccc} & \mathbf{1 9 1 1} & \mathbf{1 9 1 1} & \mathbf{1 9 3 1} & \mathbf{1 9 3 1} & \mathbf{1 9 8 5} & \mathbf{1 9 8 5} & \mathbf{1 9 8 5} \\ \text { Distances } & \mathbf{1 9 1 1} & \mathbf{1 9 8 5} & \mathbf{1 9 3 1} & \mathbf{1 9 8 5} & \mathbf{1 9 1 1} & \mathbf{1 9 3 1} & \mathbf{1 9 8 5} \\ & & & & & & & \\ \text { East Anglia } & 64.8 & 45.8 & 59.1 & 44.3 & 72.2 & 63.6 & 55.6 \\ \text { South West } & 73.5 & 53.5 & 66.4 & 54.1 & 81.9 & 64.8 & 61.4 \\ \text { West Midlands } & 57.6 & 63.2 & 68.2 & 69.0 & 59.7 & 60.5 & 71.5 \\ \text { East Midlands } & 54.0 & 61.7 & 62.9 & 64.0 & 55.3 & 57.8 & 66.7 \\ \text { North West } & 84.6 & 86.2 & 94.5 & 92.6 & 77.6 & 76.1 & 79.3 \\ \text { Yorks \& Humb } & 67.0 & 67.8 & 74.8 & 72.9 & 67.2 & 66.1 & 70.9 \\ \text { North } & 70.6 & 43.3 & 57.6 & 44.6 & 78.2 & 58.0 & 47.5 \\ \text { Wales } & 75.1 & 49.2 & 63.5 & 48.8 & 81.0 & 62.8 & 53.6 \\ \text { Scotland } & 66.6 & 36.6 & 51.5 & 37.2 & 72.1 & 50.6 & 37.5\end{array}$

Source: derived from data in Table 5 but 1985 market potential adjusted to achieve comparability with 1911 through aggregating foreign countries' GDP to one location rather than separate regions. 
Appendix Table 1. Market Potential Relative to London \& South East Using Unadjusted Geary-Stark Method Throughout (\%)

$\begin{array}{lrrrrrrr} & \mathbf{1 8 7 1} & \mathbf{1 8 8 1} & \mathbf{1 8 9 1} & \mathbf{1 9 0 1} & \mathbf{1 9 1 1} & \mathbf{1 9 2 1} & \mathbf{1 9 3 1} \\ \text { East Anglia } & 63.8 & 63.9 & 64.0 & 63.9 & 65.6 & 62.7 & 59.1 \\ \text { South West } & 73.2 & 74.2 & 77.0 & 74.5 & 75.3 & 71.1 & 66.4 \\ \text { West Midlands } & 67.4 & 67.2 & 65.0 & 60.4 & 60.8 & 71.5 & 68.2 \\ \text { East Midlands } & 62.2 & 61.2 & 60.0 & 55.3 & 55.9 & 66.0 & 62.9 \\ \text { North West } & 97.8 & 99.0 & 97.5 & 90.0 & 89.2 & 100.8 & 94.5 \\ \text { Yorks \& Humb } & 74.8 & 74.9 & 73.9 & 70.2 & 70.1 & 78.5 & 74.8 \\ \text { North } & 66.0 & 67.7 & 71.4 & 72.5 & 72.4 & 66.1 & 57.6 \\ \text { Wales } & 70.1 & 72.8 & 74.9 & 75.4 & 76.2 & 69.5 & 63.5 \\ \text { Scotland } & 66.0 & 63.4 & 66.3 & 68.1 & 67.5 & 60.3 & 51.5\end{array}$

Source: derived from wage-based estimates of GDP using sources as in Table 1. 


\section{$\underline{\text { References }}$}

Anthony, R. (1993) The Scottish agricultural labour market, 1900-39: a case of institutional intervention, Econ. Hist Rev. 46, 558-74.

Armstrong J. (1987) The role of coastal shipping in UK transport: an estimate of comparative traffic movements in 1910, J. Transp. Hist. 8, 164-78.

Bairoch P. (1993) Economics and World History Harvester Wheatsheaf, London.

Cain P. J. (1980) Private enterprise or public utility?: output, pricing and investment on English and Welsh railways, 1870-1914, J. Transp. Hist. 1, 9-28.

Clark, C., Wilson, F. and Bradley, J. (1969) Industrial location and economic potential in Western Europe, Reg. Studies 3, 197-212.

Crafts, N. (2004) Regional GDP in Britain, 1871-1911: some estimates, Department of Economic History Working Papers in Large Scale Technological Change No. 03/04, London School of Economics.

Crafts, N. And Mulatu, A. (2004) What explains the location of industry in Britain, 1871-1931 ?, CEPR Discussion Paper, forthcoming.

Estevadeordal A., Frantz B. And Taylor A. (2002) The rise and fall of world trade, 1870-1939, NBER Working Paper No. 9318.

Foxwell E. And Farrer T. (1889) Express Trains: English and Foreign. Smith, Elder \& Co., London.

Gordon, M. (1941) Barriers to World Trade. Macmillan, New York.

Geary F. And Stark T. (2002) Examining Ireland's post-famine economic growth performance, Econ. J., 112, 919-35.

Great Britain (1940), Report of the Royal Commission on the Distribution of the Industrial Population, Cmd 6153. 
Heston, A. (1983) National income, in Kumar, D. (Ed), The Cambridge Economic History of India, vol. 2. Cambridge University Press, Cambridge.

Kaukiainen Y. (2003) How the price of distance declined: ocean freights for grain and coal from the 1870 s to 2000 , mimeo, University of Helsinki.

Keeble D., Owens P. L. And Thompson C. (1982) Regional accessibility and economic potential in the European Community, Reg. Studies, 16, 419-32.

Leamer, E. E. (1997) Access to western markets and eastern effort levels, in Zecchini, S. (Ed), Lessons from the Economic Transition. Kluwer Academic Publishers, Dordrecht.

Lee C. H. (1971) Regional Economic Growth in the United Kingdom since the 1880s. McGraw-Hill, London.

Lee, C. H. (1979) British Regional Employment Statistics, 1841-1971. Cambridge University Press, Cambridge.

Midelfart-Knarvik K. H., Overman H. G., Redding, S. J. and Venables, A. J. (2000) The Location of European Industry. Report to the Directorate General for Economic and Financial Affairs, European Commission.

Ministry Of Labour (1921) Standard Time Rates of Wages and Hours of Labour. Cd. 1253.

Ministry Of Labour (1929) Standard Time Rates of Wages and Hours of Labour. Cd. 3879.

Ministry Of Labour (1931) Twentieth Abstract of Labour Statistics. Cd 3831.

Mitchell, B. R. (1988) Abstract of British Historical Statistics. Cambridge University Press, Cambridge.

Northern Ireland Economic Council (1994) The Implications of Peripherality for Northern Ireland. Belfast. 
O'Grada, C. (1994) Ireland: a New Economic History, 1780-1939. Oxford University Press, Oxford.

Prados De La Escocura L. (2000) International comparisons of real product, 1820-1990: an alternative data set, Exp. Econ. Hist., 37, 141.

Scott, P. (2002), British railways and the challenge from road haulage: 1919-39, Twentieth Century Brit. Hist., 13, 101-20.

Sivasubramonian, S. (1997) Revised estimates of the national income of India, 1900-1 to 1946-7, Indian Econ. and Soc. Hist. Rev., 34, 113168.

Walker, G. (1942) Road and Rail. Allen and Unwin, London. 


\section{LONDON SCHOOL OF ECONOMICS}

DEPARTMENT OF ECONOMIC HISTORY

\section{WORKING PAPERS IN LARGE-SCALE TECHNOLOGICAL CHANGE}

For further copies of this, and to see other titles in the department's group of working paper series, visit our website at:

http://www.Ise.ac.uk/collections/economichistory/

01/04: $\quad$ Steam as a General Purpose Technology: A Growth Accounting Perspective Nicholas F.R. Crafts

(First published as 75/03 in the Department of Economic History Working Papers Series).

02/04: Quantifying the Contribution of Technological Change to Economic Growth in Different Eras: A Review of the Evidence

Nicholas F.R. Crafts

(First published as 79/03 in the Department of Economic History Working Papers Series).

03/04: Regional GDP in Britain, 1871-1911: Some Estimates Nicholas F.R. Crafts

04/04: $\quad$ Market Potential in British Regions, 1871-1931

Nicholas F.R. Crafts 